\title{
Psychiatry in Albania
}

Ashoka Prasad, Consultant Psychiatrist, Whipps Cross Hospital, Leytonstone

The very mention of Albania conjures up the wildest fantasies. For years we have been hearing about this 'most closed society in the world' where 'people are locked up for watching football on television', the roads of which are lined up with horse-carts, the only place in the world where no cars are seen and where dissent from the state is dealt with by Stalinistic means.

In fact, the only positive aspects of this mysterious place that I seemed to recollect were Byron's flowing tributes to the 'charming women of this region, perhaps the prettiest in the world' and that this country remains the birthplace of the Nobel peace prize winner, Mother Teresa (although she would not probably be welcome in Albania today!).

It was not surprising therefore that I embarked on this journey with a great many apprehensive notions. I expected to find a poor third world country where hunger was rampant, freedom of speech was strictly curtailed and the inhabitants with a tense expression that is so very often found in countries ruled by authoritarian regimes. I had been warned that the border post has a barber to ensure that no one with long hair or beard is let through. I had also been told not to carry religious literature or politically controversial material as it was likely to be confiscated at the border. The coach journey from Titograd to the Albanian border was often punctuated by dismayed calls from fellow passengers who had somehow forgotten to comply with these tedious regulations.

To our amazement, what we found was a relatively prosperous country self-sufficient in food and energy needs (it exports power to Greece and Yugoslavia), and exceedingly rich in minerals where people wore a relaxed expression and displayed a unique brand of friendliness. Indeed, there are no private cars but it is not unusual to stumble across every European make (Mercedes seems to be the favourite!) used for official purposes. There is also a ban on religious literature of any kind as Albania is officially an atheist state but certainly it is no more prohibitive than many other states where practice of any religion other than the officially approved one is regarded a crime. Television is widely popular and there is no basis at all to the report that watching football is punishable. I did not see any barber waiting for us at the border post; incidentally many in the party did have long hair and beard and passed through without hindrance.

The history of Albania is a history of survival of the original Albanians-the Illyrians. For several hundred years the country was ruled by the Serbs and later on the Turks (contrary to the popular view, the Normans had already withdrawn in the early twelfth century). There was a brief glimmer of hope in the fifteenth century when Skanderberg, the national hero, led the people against the Turks and resisted the Ottoman invasion. But this proud period was a brief interlude in historical terms as only six years after Skanderberg's death, his son sold Kruje, an important centre, to the Venetians. Only six years later the Ottoman empire subdued the entire country and this occupation was to last until 1912 when the first national government was formed. A year later the London Conference designated the Albanian boundaries, but, almost in a matter of months, the country went into turmoil again when it was first ruled by Prince von Wied and later occupied by the Greek forces. Soon afterwards the country was ruled by the poet and historian Fan Noli who was overthrown by a tribal chief Ahmet Zogu, an Italian protegé who proclaimed himself the President and later on the King. Ironically it was the Italian invasion which led to his downfall and he fled to London where he formed a government in exile and later on lived in the Middle East until his death protected by a bodyguard (despite his seven feet stature!).

The Albanian Communist Party, later renamed the Albanian Labour Party, was formed by Enver Hoxha and his associates and they ruled the country until Hoxha's death in 1985. It is quite obvious that he is still revered in the country. His portraits are to be seen everywhere and even the mountains are adorned with limestones reading 'Parti Enver' (Enver's party). Hoxha enjoyed Stalin's support and the numerous statues of Stalin that one sees in the country are probably a reflection of intense loyalty, rather than a tacit endorsement of Stalin's policies! The country broke off with Tito's Yugoslavia, Khruschev's Russia and post-Mao China accusing them of betraying 'Marxism-Leninism' and adopting capitalistic philosophies. Despite his death, it is abundantly clear that Hoxha still remains the pivotal figure and his writings and anecdotes are to be found in as diverse places as a carpet factory and the University of Tirana now renamed Enver Hoxha University.

Even the country's fiercest critics would be hard put to deny that it has made tremendous strides in industrial and economic terms. The Albanians are certainly very proud of this and the achievement is even more remarkable when one considers that it has been a closed society for years (being shunned by both superpowers and having little contact with other countries). One might contend that the price paid for this development has been total denial of religious freedom, and mosques and churches being converted to assembly halls or cinemas but, on the whole, the Albanians that I spoke to seemed to be quite content with their lot.

In educational terms the country has made remarkable strides to achieve an almost total eradication of illiteracy in post-war generations. They have institutes for foreign languages affiliated to the University and the testimony to their training was my courier, a university academic who spoke flawless English, French and Italian. His English was far superior to that spoken in many other countries I have 
visited where the language is used much more widely.

In 1938 there were about 10,000 people being looked after

by a single doctor. In 1983 the figure was 580 , which speaks for itself. The figure is comparable to any advanced country.

Since 1947 the Health Ministry has been publishing The Bulletin of Medical Science through the University of Tirana. There is also a Bulletin of Translations, from Foreign Medical Literature and The Medical Review provided free of charge to every hospital library.

The psychiatric services in the country have to be assessed in the context of the overall health service structure. The speciality combines neurology as well and hence is known as neuro-psychiatry.

The University Department is located in a large psychiatric hospital in the capital city, Tirana. It is headed by Professor Bajaraja Praha and Dr Nestor Polimeri who is the hospital superintendent. I was entertained in the department after my visit was cleared through the Committee for Friendly Relations on the Albanian Society's recommendations. To my surprise, although most of the staff spoke English, there had not yet been any visit from a psychiatrist from an English-speaking country. The last Western psychiatrist to visit was Professor P. Pichot from France.

Needless to say, the entire mental health care system is state-funded with no provision for private practice. The main psychiatric centre is based in Tirana but there are a number of other hospitals catering to the local needs e.g. a large hospital in Shkodhra is responsible for the northern part of the country whilst the one near Saranda has a catchment area encompassing the southern region. However al the complicated cases are referred to Tirana.

The general neuro-psychiatric hospitals have roughly equal numbers of psychiatric and neurologic patients. It is quite usual to find patients suffering from strokes and epilepsy within these settings. Of the psychiatric patients, the schizophrenics tend to dominate by $2: 1$ over those suffering from an affective illness and other forms of neuroses requiring in-patient treatment.

Psychotherapeutic techniques have, so far, not been viewed favourably by Albanian psychiatrists. Nevertheless they are quite up to date in all forms of biological therapies. It is quite common to find schizophrenics being maintained on depot medication and undergoing a rehabilitation programme on which the department is laying considerable emphasis. Within the hospital itself the psychotics are generally maintained on neuroleptics/antidepressants with occupational therapy support.

There is a very well-equipped child psychiatric depart- ment in Tirana where they tend to get referrals from all over the country. The senior child psychiatrist has a special interest in childhood depression, hence the five in-patient beds available to this sub-speciality reflect this interest. However, as in the West, most child psychiatric practice is conducted through out-patient attendances.

It is unusual to find a mentally handicapped patient within these settings but I was told that there were special homes for the mentally handicapped where the more dependent cases were referred. The remainder stayed with their families and fully availed of the 'special schools' provided for by the state.

The University Department is quite actively involved in research. I was impressed to see the DSM-III being used quite widely. The department also has a wide supply of international journals such as Psychological Medicine, Journal of Psychiatric Research and American Journal of Psychiatry. There are three 600-paged Albanian books on psychiatry, all of which have a very impressive reference list (considering they have to get every scientific article translated). The current interests of the department include childhood depression, DST, combination antidepressant therapy and behavioural therapy in obsessive-compulsive disorder.

The psychiatric training commences a year after graduation after the graduate has completed the compulsory year at a district general hospital. The entire process takes about four years and there is no examination at the end of it. Many of the trainees get to spend some time in the University Department in Paris with whom the department has close links.

Overall, the picture of Albanian society that I got was that of dogged self-determination and hard work and the department of psychiatry was certainly no exception. Whilst there are certain aspects e.g. absolute prohibition on photographing carpet factories or soldiers and lack of any religious institutions, which may appear unusual to an observer from the West, the society is clearly not as closed as it appears. An epilogue to this last statement: after having been lavishly entertained to the lovely Albanian traditional drink, 'raki', Professor Bajaraja Praha told me that he was in London during the War with the Red Cross. He was then introduced to King George VI and Queen Elizabeth. 'I saw her a few days ago on TV celebrating her eighty-fifth birthday', he said, 'she hasn't changed at all-she's as lovely as ever.'

I am sure the Queen Mother would be delighted to hear this compliment-somehow I do not know the means of communicating it to her! 